\title{
CHALLENGES FACED BY MIDDLE LEVEL MANAGERS IN THE DECISION MAKING PROCESS: A CASE OF G4S SECURITY SERVICES (K) LIMITED - NAIROBI REGION
}

\author{
Jonyo Bonn Odera Msc Od. \\ United States International University-Africa, Kenya
}

Doi: 10.19044/elp.v1no2a14 URL:http://dx.doi.org/10.19044/elp.v1no2a14

\begin{abstract}
The purpose of the study was to determine the factors that contribute to the Challenges of Middle Level Managers in the Decision Making Process A Case s of G4S Security Services (K) Limited, Nairobi region. The literature review examined the various historical and theoretical perspectives of the decision making process in organization in terms of; the traditional roles of managers and how they relate to their work dynamics; the organizations structure and it's impact on the decision making component. Lastly, the specific challenges faced by managers in the middle level hierarchy in the decision making process.

The methodology of the study was descriptive case study. A census method was used to collect the data in the study. Respondents assert that the hierarchical nature of the structure of the organization contributed largely to the exclusion of the middle level managers in the organizations decision making process. Managers' inputs in strategic planning is increasingly becoming necessary in the formulation of practical and directed strategies important at implementation stages as they understand what is significant at the operations level and so that they may own the process to reduce resistance to change in organizations.

Organizations should position themselves by empowering managers in decision making and strategic formulation to get a competitive advantage with the competition. It would therefore be recommended that the vital input component of middle level managers be incorporated into the management's decision making process in the organizations' formulation of policy and strategy.
\end{abstract}

Keywords: Decision making, middle level managers, Nairobi 


\section{Introduction}

\section{Decision Making}

Identifying and choosing solutions that lead to a desired end result (Dessler, 2008).

\section{Development}

A learning exercise that is directed towards future needs rather than present needs and is concerned more with career enhancement and growth than immediate task (Dessler, 2008).

\section{Training}

The learning exercise directed towards the acquisition of specific knowledge and skills for the purpose of occupation or task (Dessler, 2008).

\section{Strategy}

Large scale, future-oriented plans for interacting with the competitive environment to achieve organizational objectives (Kreitner, 2007).

I.

\section{Introduction}

The chapter describes the research design adopted in the study, population and sample frame, sample size, research technique, data collection and analysis methods and research procedures. The function of the research design is to provide for the collection of relevant evidence with minimal expenditure of effort, time and money. The research design is to provide for the collection of relevant data in order to analyze/process to show the findings (Orodho, 2004). The population of the research consisted of 10 senior managers who conceptualize or make company policies, 50 junior level staff (supervisors) of different divisions and 45 middle level managers from G4S Security Services Nairobi.

\section{Data Analysis Methods}

Data analysis is a process of gathering, modeling, and transforming data with the goal of highlighting useful information, suggesting conclusions, and supporting decision making. Data analysis has multiple facets and approaches, encompassing diverse techniques under a variety of names, in different business, science, and social science domains (Orodho, 2004). The data was analyzed using qualitative and quantitative statistical methods.

In summary, the chapter describes the methodology used in the research; The research design is descriptive case study; The population of the 
study comprise of senior managers, middle level managers and supervisors at G4S Security Services Nairobi region and The statistical method used was non probability.

\section{Results and findings \\ Introduction}

The questionnaire covered the demographic information of the respondents, their gender, and age, highest level of education, job designation and length of service to the company. The information and data obtained was presented in form of frequency tables, bar charts and pie charts. The study targeted an estimated 10 senior managers, 45 junior managers and 50 Low level supervisors all who are staff and management of the G4S organization.

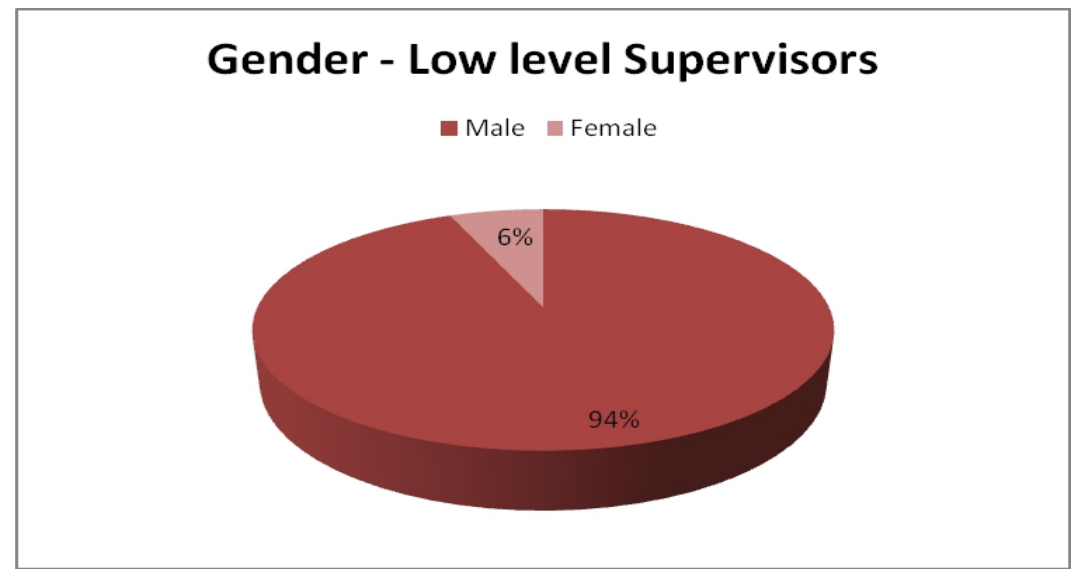

The gender of the low level supervisors indicated that the male were the majority representing $93.8 \%$ while the females represented only $6.2 \%$ of this level of staff

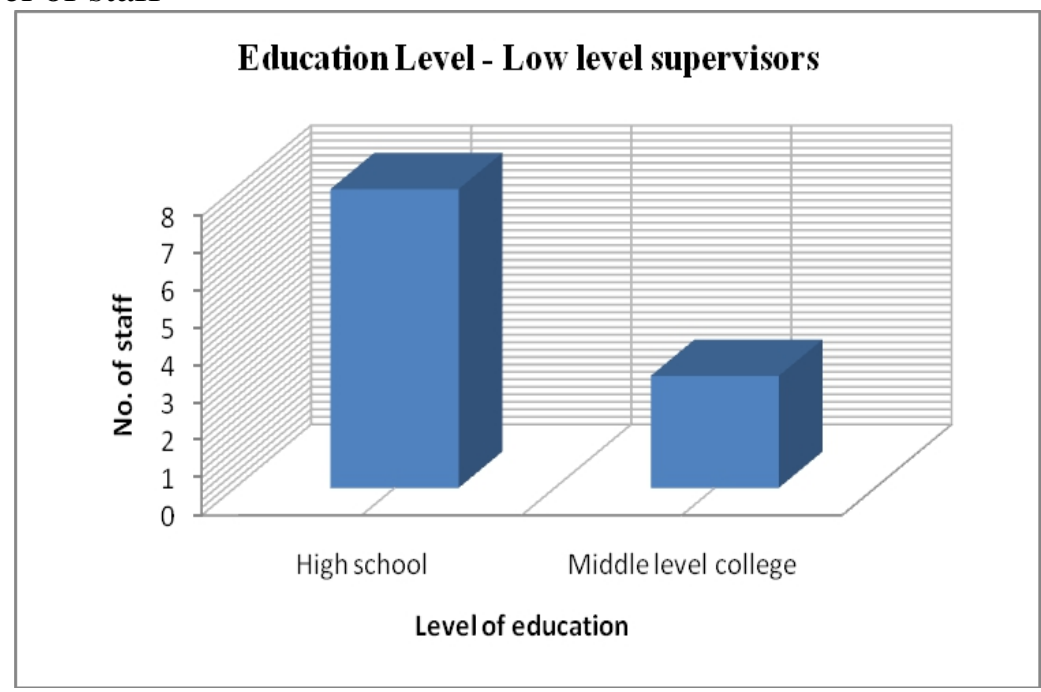


Education Levels of low level supervisors

The results show that the highest level of education attained by the participating low level supervisors $72.7 \%$ have achieved a High or Secondary school education, followed by $27.3 \%$ who have gone up to middle level college education.

Table 4.3.5.1 Length of service - Low level supervisors

\begin{tabular}{|c|c|c|c|c|}
\hline & Low level supervisors & \multicolumn{2}{|c|}{ Frequency } & Percent \\
\hline \multirow{4}{*}{ Valid } & $1-4 \mathrm{yrs}$ & \multicolumn{2}{|c|}{9} & 52.9 \\
\hline & $5-9 \mathrm{yrs}$ & \multicolumn{2}{|l|}{4} & 23.5 \\
\hline & 10yrs and above & \multicolumn{2}{|l|}{2} & 11.8 \\
\hline & Low level Supervisors & Frequency & Percent & \\
\hline \multirow{3}{*}{ Valid } & Male & 15 & 88.2 & \\
\hline & Female & 1 & 5.9 & \\
\hline & Total & 16 & 94.1 & \\
\hline Missing & System & 1 & 5.9 & \\
\hline Total & & 17 & 100.0 & \\
\hline
\end{tabular}

The gender of the low level supervisors indicated that the male were the majority representing $93.8 \%$ while the females represented only $6.2 \%$ of this level of staff.

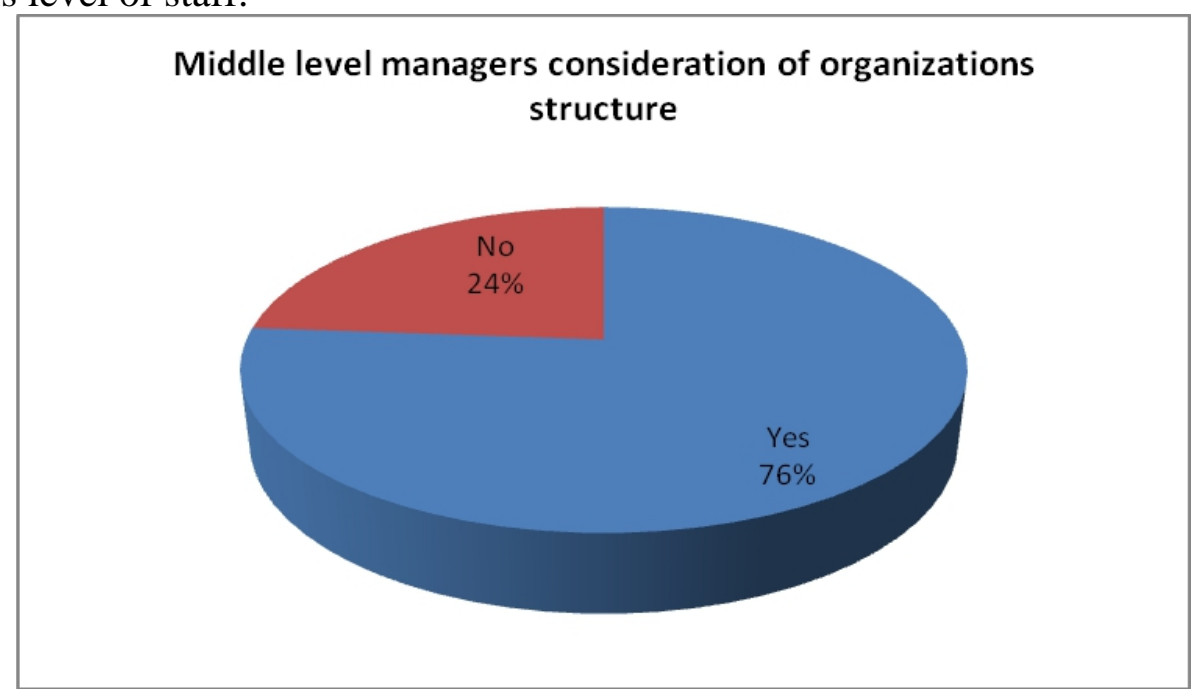

Analyzing the organizational structure revealed that $76.2 \%$ of middle level managers agreed that it was good and served the company well while $23.8 \%$ did not agree.

Other results indicate as follows:

- The middle level managers provided the following reasons for their responses with $23.8 \%$ stating that this supports the fact that the 
structure was good because the operations of the company run smoothly with the structure in place.

- Analyzing the organizational structure revealed that $80 \%$ of senior managers agreed that it was good and served the company well while $20 \%$ did not agree.

- The senior managers provided the following reasons for their responses with $33.3 \%$ stating that this supports the fact that the structure was good because the operations of the company run smoothly with the structure in place, with a similar $33.3 \%$ indicating that with the structure there were clearly defined reporting lines.

- Analyzing whether the low level supervisor were satisfied with their current job position revealed that $64.7 \%$ of them were satisfied with their position in the company currently whereas $35.3 \%$ were dissatisfied with their current positions.

- The low level supervisors provided the following reasons for their responses with $29.4 \%$ stating that they were contented with their positions while $23.5 \%$ were dissatisfied saying that their pay was too low hence are discontented with the position.

- Analyzing whether the middle level managers were satisfied with their current job position revealed $19 \%$ of them were satisfied with their position in the company currently whereas $81 \%$ were dissatisfied with their current positions.

- The low level supervisors provided the following reasons for their responses with $23.8 \%$ stating that they were dissatisfied with their positions because there was no promotion while another $23.8 \%$ were dissatisfied saying that their pay was too little hence are discontented with the position.

- An analysis of whether the middle level managers are assigned enough duties revealed that $23.8 \%$ agreed that they are all the time assigned enough duties while $66.7 \%$ stated that sometimes they are assigned enough duties and $9.5 \%$ said they are rarely assigned enough duties.

- The low level supervisors provided the following reasons for their responses with $23.5 \%$ stating that they sometimes lack the equipment they require to do their duties, $17.6 \%$ stated that supplies took too long to be availed thus delaying their duties, another $17.6 \%$ said that they use improper kit to perform their duties while a proportionate $17.6 \%$ stated that they never lack the items they need for their duties.

- The low level supervisors provided the following reasons for their responses with $76.5 \%$ stating that they communicate openly thus creating a conducive atmosphere for good communication, $11.8 \%$ 
stated that the boss encourages and empowers with his communication while $5.9 \%$ said it is because he communicates company information and a comparable $5.9 \%$ said it is because s/he is a leader.

- To determine from the low level supervisors whether the boss delegates duties to them revealed that $82.4 \%$ of the respondents stated that duties are delegated to them all the time while $17.6 \%$ said that they are sometimes delegated duties.

- An analysis of the middle level managers training needs revealed $57.1 \%$ felt they needed training in management and $28.6 \%$ need training in customer care and services.

- Analyzing the job motivation of the low level supervisors revealed that $58.8 \%$ of the respondents stated that they are only sometimes motivated by their jobs, $35.3 \%$ said that the job motivates them all the time whereas $5.9 \%$ stated that the job rarely motivates them.

- Analyzing the job motivation of the middle level managers revealed that $66.7 \%$ of the respondents stated that they are only sometimes motivated by their jobs, $9.5 \%$ said that the job motivates them all the time whereas $23.8 \%$ stated that the job rarely motivates them.

- The senior managers provided the following reasons for their responses with $33.3 \%$ stating that good allowances would motivate them, another $33.3 \%$ stating that merit performance rewards would motivate them while $16.7 \%$ stating that an increase in salary would motivate them and a comparable $16.7 \%$ would be motivated with improved and better working conditions.

- An assessment of the senior managers to determine if they were team players revealed that $83.3 \%$ of the respondents indicated that they are team players while $16.7 \%$ indicated that they were not team players.

- The middle level managers' response on the activities that need to be done to enhance teamwork revealed that $33.3 \%$ advocated for equality and fairness at work which would enhance team building, 9.5\% stated that avoiding the practice of tribalism and favoritism would enhance team work and a similar $9.5 \%$ advocated for regular team building meetings

- The low level supervisors provided the following responses as obstacles to their work $47.1 \%$ indicated that there were no obstacles to their work, $11.8 \%$ indicated that lack of resources to perform their duties was an obstacle to their work while others in equal measures of $5.9 \%$ indicated that the communication links were too large, they used defective equipment hindering the progress of their work, they had different opinions with their superiors thus hindering their work, 
overcrowding at the working place and poor communication at work respectively hindered the work progress.

- The senior managers provided the following responses as obstacles to their work $33.3 \%$ indicated that inadequate resources were obstacles to their work; another $33.3 \%$ indicated that little salary was an obstacle to their work whereas $16.7 \%$ indicated that the impromptu transfers were an obstacle and another $16.7 \%$ complained of inadequate office space.

- Analysis shows that $67 \%$ of the senior managers consider their managers as multi-skilled as opposed to $33 \%$ who do not have the same opinion.

\section{Conclusion}

The managers by necessity need also to be involved in the formulation and planning of the overall organizational strategy. This will ensure they understand the strategies and own the process hence are not alienated from the process thus making them have a feeling which may produce negative synergy in the organization leading to a conflict situation of staff segregating themselves into groupings of them versus us.

The organization's structure is influenced by several key components in the organization which direct the way it is run and managed. The hierarchical structure of G4S $(\mathrm{K})$ where decisions and strategies are made from the top and communicated to the middle level management down the line explains why the middle level managers are not actively involved in the process. Since organizational structure determines largely the manner and extent to which roles, power and responsibilities are delegated, controlled and coordinated, the middle level managers in this kind of structure become mere implementers of policies set by the top management because the system has subordinated them - both by role and job description - as entities for communicating the organizational strategies down the chain of command.

The job description and the organizational role of the managers are very specific and has consequently compromised their participation in the decision making process as their roles are outlined and restricted to the implementation of organizational policies. G4S (K) as exhibited from the respondents adapts the hierarchical structure thus alienating middle level managers from active participation in the decision making process but rather are passive actors, communicators and implementers. The top management therefore ascribes no decisional responsibility to the middle level management and thus the reason for their exclusion from the decision making process. 


\section{Recommendations}

The managers' inputs in strategic planning is increasingly becoming necessary in the formulation of practical and directed strategies important at implementation stages as they understand what is significant at the operations level and so that they may own the process to reduce resistance to change in organizations.

The ever changing organizational operating environment has dictated the course of direction to take without which some firms either will face acquisitions, mergers or total closure. Organizations should position themselves by empowering their managers in decision making and strategic formulation to get a competitive advantage with the competition.

The vital input component of middle level managers be incorporated into the management's decision making process in the organizations formulation of policy and strategy.

There may be a need for further research to determine the extent to which organizations can build managerial capacity of middle level management staff in order to give them some leverage in terms of making/taking major or critical decisions in organizations as opposed to the current scenario as witnessed in G4S in Nairobi and around the country. Further research may be required to determine the relevant training needs of various cadre of staff in an organization that are in line with the changing global trends, modern life's demands and realities of the organizational and business management environment.

\section{References:}

Alavi, M. and Leidner, D.E. (2004). "Knowledge Management and Knowledge Systems:

Conceptual Foundations and Research Issues; MIS Quarterly, 25(1) 107-136. Ansoff, A. I. and McDonnell E.J. (1990). Implanting Strategic Management Prentice Hall, UK.

Anthony, W.P., Kacmar, M. K. and Perrewe, P. L. (2006) Human Resource Management:

Strategic Approach. Thomson Custom Solutions, USA

Bartlett, J. E.II, Kotrlik, J.W. and Higgins, C. (2001). Organizational research:

Determining appropriate sample size for survey research. Information Technology, Learning, and Performance Journal, 19(1) 43-50.

BusinessDictionary.com (2009) Online Business Dictionary. Retrieved on 15.11.2009

www.businessdictionary.com

Carrillo, P. (2004) "managing knowledge: Lessons from the oil and gas sector", Construction Management and economics, vol.22.No.6. Pp.631-42 
Cole, G.A. (1996), Management Theory and Practice (5 ${ }^{\text {th }}$ edition) New York, ELST USA.

Cornall, C. (1995), Managing Change in organizations, $2^{\text {nd }}$ edition, London, Pentice Hill.

Cooper R. D. and Schindler, P. (7th Ed), Business Research Methods

McGraw-hill New York

Davenport, T. and Pusek, L. (1998). Working Knowledge: How organizations manage what they know, Harvard Business School Press, Boston, MA.

Davidmann, M. (1998) Role of Managers under Different Styles of Management Retrieved October 13-2009 from

http:Iwww.solhaamorg/articles/clm2su.html

Denscombe, M. (1999).The Good Research Guide, Philadelphai, USA.Open University Press.

Dessler, G. (2008) Human Resource Management, Upper Saddle River, New Jersey- Prentice Hall.

Donnnelly, J., Gibson, J. and Ivancevich, J. (1987) Fundamentals of

Management. Chicago: Irwin Business Publication Inc.

Folino D.F. (1997), The Agile Manager's Guide to Making Effective Decisions, Velocity Business Publishing, Inc. USA.

Frame, J. D. (1987), Managing Project in Organizations: How to make use of time, techniques and people, San Francisco: Jossey-Bass Publishers.

Gross, S. (1993), The Ten Most Common Organizational

Problems:managementassistance.org/page4e.html.

Hall, D.J. and Paradice, D. (2005) "Philosophical Sharing culture: a case study ", Journal of information and knowledge management, vol.3.No.2,pp.135-142

Hamilton, A. (1995).Management Audit: maximizing your company's efficiency and effectiveness, New Jesey, Alexander Hamilton Institute.

Holden L. (2004) Leicester Business School Journal of Managerial Psychology, Demontfoot University, UK.

Ireland R. D. (2005), Entrepreneurship, Theory and Practice, The Gale Group Baylor University, UK.

Jackson, A.C. and Donovan, F. (1999) Managing to survive: Managerial practice for not for profit organizations. Buckingham: Open University Press.

Jones, G. R., and Jennifer M. G. Contemporary Management. $4^{\text {th }}$ ed.New York, NY: McGraw-Hill Irwin, 2006

Kish, L (1995) Survey Sampling, Wiley, ISBN 0-471-10949-5

Korn, E. L. and Graubard, B. I. (1999) Analysis of Health Surveys, Wiley, ISBN 0-471- 13773-1

Kreitner, R. (2004), Management, Hughton M. Co. Boston. 
Kreitner, R. and Kinichi, A. (2007) Organizational Behavior, McGraw-Hill International $9^{\text {th }}$ edition.

McKenna, E. (2000), Business Psychology and Organizational Behaviour A Student's Handbook. Taylor and Francis Inc,USA

Mintzberg, H., Raisingheni, D. and Theoret, A (1976), The Structure of unstructured decision processes; Administrative Science Quarterly, vol.21.no.2 pp.246-75.

Morgan, G. (2008) Towards a New Industrial: Workers Participation in Industry, Routlege and Kegan Paul, London.

Ochanda, M. R. (2002) Factors influencing the effective implementation of Microfinance schemes in Kenya, (Thesis)

Orodho, J.A. (2004).Techniques of writing research in education and social sciences, Masola Publishers, Nairobi.

Polanyi, M. (2004) The Tacit Dimension, Routlege and Kegan Paul, London. Pyzdek, T. (2008) Organizations and Their Functions.

Retrieved on October 13, 2009,

http:Ilwww.qualityamerica.com.knowledgecente cqmmgrrole.html.

SIMMERING, J.M. (2010) MANAGEMENT LEVELS: REFERENCE FOR BUSINESS

Encyclopedia of Business, 2nd ed. Retrieved on 08/03/2011 from http://www.referenceforbusiness.com/management/Log-Mar/ManagementLevels.html

Thompson, R. (1997), Managing People. Oxford Butterworth- Heinemann.

Watson, T.J, (2004) In Search of Management, Routledge, London

William, D. (2003) The Middle Ground; Developing Mid-Level Managers for Strategic Change.

Wright, P. and Noe, R. (1995) Management of Organizations, Chicago, Irwin. 